\title{
.
}

JURNAL TRANSFORMATIF

http://e-journal.iain-palangkaraya.ac.id/index.php/TF
Vol. 3, No. 1

Apr 2019

\section{KESALEHAN MUALAF DALAM BINGKAI KEISLAMAN}

\author{
Zainap Hartati ${ }^{1}$ \\ Pascasarjana IAIN Palangka Raya \\ email: zainap.hartati@iain-palangkaraya.ac.id
}

Received : 2019-04-02 ; Accepted : 2019-04-18 ; Published : 2019-05-16

\begin{abstract}
The development of converts in Central Kalimantan is quite widespread in several districts/cities, but its existence still needs a joint commitment to foster and guide the understanding and guidance of religion in the strict teachings of Islam. Based on this matter, this research was carried out with the formulation of how piety when they convert to Muslim, with the aim of analyzing the piety of converts in their Islamic practices in Central Kalimantan. The method used in this research is interviews, observation and documentation. The results obtained that the piety of converts as a Muslim appears in routine activities such as prayer and fasting which are still immature understood and actualized in daily life. Their motivation to become a Muslim is more dominant because of marriage, but there are many factors that characterized Islam, such as the family environment, the surrounding community and their motivation to convince their faith in Islam as their religion.
\end{abstract}

Keywords: piety, converts, Islamic

Negara menjamin kemerdekaan tiap-tiap penduduk untuk memeluk agamanya masing-masing dan kepercayaannya", bunyi Undang-undang Dasar 1945 pasal 29 ayat (2). Konteks pasal tersebut menggambarkan akan kebebasan penduduknya (warga negara Indonesia) untuk menentukan sendiri agama yang akan dianutnya demikian juga dalam melaksanakan keyakinannya. Selanjutnya beragam agama yang ada di bumi Kalimantan Tengah dengan gaung "Bumi Pancasila" tertuang pada sila " Ketuhanan yang Maha Esa" dalam hal ini pengakuan keberagaman pada sisi agama yang ada di masyarakat Kalimantan

1 Dosen IAIN Palangka Raya, Alamat. Jl. Yos Sudarso No, 104 Palangka Raya, Kalimantan Tengah, email : zainap.hartati@iain-palangkaraya.ac.id, nomor Hp. 0811521059

DOI : 10.23971/tf.v3i1.1235

Transformatif (Journal Islamic Studies), Vol. 3 No.1, Hal 1-18

Copyright $\odot 2019$ by Transformatif, p-ISSN 2580-7056; e-ISSN 2580-7064 


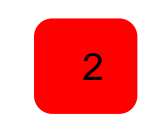

Tengah, namun demikian beraga suku, budaya dan bahasa juga mewarnai bumi Kalimantan Tengah. ${ }^{2}$

Bukan suatu pelanggara jika seseorang berpindah keyakinan atau agama kepada keyakinan/agama yang lain, Fenomena ini adalah merupakan kejadian yang biasa ditengah masyarakat, Dalam ajaran Islam mereka yang masuk ke agama Islam disebut dengan mualaf. Tren ini berkembang /bertambah dari tahun ke tahun, sehingga perkembangan jumlah penduduk Islam di wilayah Kalimantan Tengah yang tersebar di beberapa kabupaten yaitu 13 kabupaten dan 1 (satu) kota cukup signifikan keberadaan para muallaf. Kalimantan Tengah merupakan salah satu pulau terbesar (Pulau Kalimantan) yang ada di kepulauan Indonesia, memiliki 14 (empat belas) kabupaten/kota yaitu : (1) Kabupaten Barito Selatan (Buntok); (2) Kabupaten Barito Timur (Tamiyang Layang); (3) Kabupaten Barito Utara (Muara Teweh); (4) Kabupaten Gunung Mas (Kuala Kurun); (5) Kabupaten Kapuas (Kuala Kapuas); (6) Kabupaten Katingan (Kasongan); (7) Kabupaten Kotawaringin Barat (Pangkalan Bun); (8) Kabupaten Kotawaringin Timur (Sampit); (9) Kabupaten Lamandau (Nanga Bulik); (10) Kabupaten Murung Raya (Puruk Cahu); (11) Kabupaten Pulang Pisau (Pulang Pisau); (12) Kabupaten Sukamara (Sukamara); (13) Kabupaten Seruyan (Kuala Pembuang); (14) Kota Palangka Raya ${ }^{3}$

Berdasarkan data dari 14 (empat belas) kabupaten/kota tersebut terbagi lagi pada beberapa kecamatan, kelurahan bahkan anak desa dimana masyarakat yang berdomisili di wilayah tersebut tersebar sejumlah mualaf yang keberadaan mereka perlu perhatian dan pencerahan agama Islam dari tokoh masyarakat maupun umat Islam yang telah mapan ke Islamannya.

Mualaf dalam Islam menunjukkan makna seseorang yang baru masuk agama Islam indentik dengan kata konversi agama berkenaan dengan perubahan batin seseorang secara mendasar, dari kehidupan aktivitas keagamaan sebelumnya

\footnotetext{
${ }^{2}$ Pengamatan penulis bahwa sebagaimana jargon yang nampak pada baleho yang ada di Kot Palangka Raya, Kota Palangka Raya adalah Bumi Pancasila, demikian juga agama yang ada di Kalimantan Tengah yang tersebar di 13 Kabupaten dan 1 Kota : Islam, Kristen, Hindu dan Budha serta Kaharingan. Kesukuan masyarakat terdiri dari berbagai suku seperti Dayak, Jawa, Banjar, Bugis dan Madura.

3 Lihat, https://id.m.wikipedia.org, up date 1 Maret 2019.
} 
(agama sebelumnya) kepada aktivitas keagamaan yang dianut saat ini yaitu agama Islam dengan berbagai rutinitas amaliah keseharian yang wajib dikerjakan. Pengalaman batin dengan aktivitas keagamaan yang dialami oleh seseorang non muslim menjadi mualaf, maka kondisi yang demikian dalam padangan agama Islam seseorang yang telah mendapat hidayah Allah SWT untuk masuk Islam, bisa pindah dari agama satu ke agama yang lain dan orang yang baru masuk Islamlah yang disebut dengan mualaf .

Beberapa penelitian menyatakan bahwa : Makin kuat keyakinannya terhadap kebenaran pandangan hidup itu akan semakin tinggi pula nilai bakti yang ia jalani terhadap nilai-nilai Islam. Kekonsistenan mempelajari agama adalah cara muallaf untuk terus menjalankan kehidupan beragama secara berkelanjutan. Selain itu, mualaf membangun komitmen untuk tetap memegang teguh keyakinan beragamanya saat ini. Komitmen ini menunjukkan bahwa muallaf tidak hanya sekedar memahami dan menjalankan agama dengan sekadarnya, tetapi ada usaha dari dalam diri mualaf untuk terus mempertahankan keyakinannya walaupun mengalami berbagai tantangan ketika menjalankan kehidupan beragamanya. ${ }^{4}$

Penelitian tersebut menunjukkan bahwa komitmen untuk dapat menjalankan ibadah agama memerlukan komitmen dari mualaf itu sendiri, kemauan dari dirinya sendiri memberikan kekuatan untuk dapat memahami ajaran agama baru yang dijalaninya. Amaliah seseorang/mualaf merupakan bentuk kesalehan pada ajaran agama yang dianutnya. Namun demikian apakah menjadi mualaf telah diimbangi dengan amaliah ajaran agama/ keagamaan Islam sebagai suatu kewajiban bagi mualaf ?, apakah amaliah dalam agama Islam sudah menjadi konsekuensi/keharusan untuk berkomitmen menjalankan aktivitas ajaran agama Islam dengan baik dan sungguh-sungguh?. Kajian ini menarik untuk diangkat sebagai bahan dan motivasi umat Islam untuk membantu, memotivasi bahkan meluruskan pemahaman saudara seiman, untuk dapat menjalankan ajaran agama Islam dengan baik dan benar. Sehingga mualaf sebagai umat yang mendapatkan

${ }^{4}$ Titian Hakiki dan Rudi Cahyono. 2015. Komitmen Beragama Pada Muallaf ( Studi Kasus Pada Muallaf Usia Dewasa). Jurnal Psikologi Klinis dan Kesehatan mental. Vol. 4 No. 1 April. Universitar Air Langga : Surabaya. H.27 


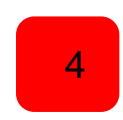

hidayah dari Allah SWT benar-benar menjadikan muslim yang sejati dalam bingkai keislamnnya. Hal ini seirama dengan Q.S. Ar-Ruum ayat 30.

Kajian pada tulisan ini sebuah catatan hasil penelitian yang dilakukan dalam menggali dan mengkaji keberadaan para mualaf di Kalimantan Tengah, Pendataan para mualaf yang masuk Islam dan fakta-fakta dilapangan terkait dibina atau tidaknya para mualaf tersebut setelah mereka beriman dan selalu terjaga suasana kebatinan dan keimanannya. Kajian tentang mualaf, dimaksudkan agar mualaf tidak terjadi pembiaran atau akidah/iman mereka, diharapkan adanya tanggungjawab penuh dari umat Islam yang bersinergi antara pemerintah dan umat Islam untuk membina mereka serta mengarahkannya, baik melalui pendidikan dan pengajaran di bidang ibadah kepada Allah SWT, ataupun santunan dana sosial melalui kontribusi badan amil zakat, infak dan sedekah serta pemberdayaan dengan modal kerja.

Selanjutnya, para mualaf/mereka memiliki kemandirian untuk beribadah bahkan kemandirian sosial dalam beraktivitas dengan lingkungan sekitarnya, kondisi ini diharapkan agar mereka merasa terayomi dan diperhatikan oleh masyarakat sesama muslim yang telah mapan keimanannya dalam menjalankan ibadah kepada Allah SWT.

Penelusuran yang diambil dengan cara wawancara, pengamatan bahkan Focus Group Discusion (FGD) dengan para mualaf dan instansi setempat (Kemenag, KUA, Penyuluh agama, ustdaz dan para dai serta Ormas Islam yang mempunyai komitmen dalam melakukan pembinaan kepada umat (khususnya mualaf). Kajian ini dilakukan agar terdata dan terinformasikan bagaimana keadaan mualaf di Kalimantan Tengah sehingga dapat diberikan model/pola pembinaan kepada mereka setelah nenjadi muslim (mualaf)

\section{METODE}

Metode yang digunakan dalam menggali tentang kajian ini, dengan pendekatan deskriptif kualitatif dan menggali data dilapangan dengan cara wawancara, observasi dan dokumentasi juga dilakukan Focus Group Discusssion (FGD). Subyek penelitian para mualaf, dai, ustadz/ustadzah, petugas Kantor 
Urusan Agama (KUA setempat), sedangkan informan Pengurus ormas keagamaan dan masyarakat setempat. Analisa data dengan deskriftif kualitatif.

\section{HASIL}

\section{Perkembangan Mualaf}

Keberadaan mualaf di Bumi Pancasila, Kalimantan Tengah pada saat ini masih kurang mendapat perhatian serius dari umat Islam itu sendiri, baik organisasi maupun lembaga Islam di Kalimantan Tengah, hal ini terjadi disebabkan oleh beberapa hal seperti :

1. Kebijakan publik belum sepenuhnya dapat mengayomi untuk pengelolaan para mualaf;

2. Domisili para mualaf berada jauh dari jangkauan dakwah Islam, menyebabkan mereka tidak terbimbing secara kontinyu;

3. Organisasi dan kelembagaan Islam tidak memiliki dana yang memadai dan tidak memiliki akses transportasi untuk menjangkau ke pedalaman dimana para mualaf berdomisil;

4. Kurang maksimal kesadaran jihad yang terkoordinir dari umat Islam khususnya dari para agniya agar memberikan kontribusi dana membantu para ustazd dan mubalig Islam yang dikhususkan untuk pembinaan mu'allaf dalam membumikan agama Islam.

5. Minimnya ketersediaan dana terutama yang berada di naungan Kementerian Agama setempat untuk melakukan pembinaan kepada mualaf

6. Kesulitan untuk menyatukan mualaf yang ada karena pendataan secara dokumen belum lengkap dan tidak terperinci.

Keberadaan mualaf ${ }^{5}$ atau orang-orang yang baru saja hijrah memeluk Agama Islam, atau mereka yang sudah bertahun-tahun, beranak cucu bahkan sudah tua membutuhkan sosok teman yang dapat memberikan dukungan moril dan perlindungan dari kecaman keluarga maupun sanak saudaranya yang mampu mengoyahkan konsistensinya dalam beragama.

5 Perpustakaan nasional RI. 2006. Ensiklopedi Hukum Islam. Jakarta, hlm. 1187. Menurut Ensiklopedi Hukum Islam5, Mualaf : (Ar.: mu'allaf qalbuh; jamak: mu'allafah qulûbuhum = orang yang hatinya dibujuk dan dijinakan). Orang yang dijinakan hatinya agar cenderung masuk Islam 
Pengaruh ajaran agama dalam kehidupan individu adalah memberikan kemantapan hati, rasa bahagia, rasa terlindungi, rasa sukses dan rasa puas, perasaan positif ini lebih lanjut akan menjadi pendorong untuk berbuat, agama dalam kehidupan individu selain menjdi motivasi dan nilai etik juga merupakan harapan. ${ }^{6}$ Agama akan memberikan warna pada kehidupan seseorang/individu maupun kelompok ${ }^{7}$. Orang yang baru memeluk agama Islam biasanya sering mengalami dilema-dilema psikologis yang memerlukan pemahaman dan pengayoman dari masyarakat (perhatian), karenanya mualaf memerlukan ketenangan dan kenyamanan dalam hidup ditengah masyarakat bahkan bimbingan yang baik dari masyarakat sebagai penguat dari kondisi psikologis seorang mualaf sehingga memperkuat pegangan dan keyakinan aqidah mereka. ${ }^{8}$

Beberapa wilayah yang ada di Kalimantan Tengah antara lain seperti : Kota Palangka Raya, Katingan, Kapuas, Pulang Pisau, Gunung Mas, Tamiyang Layang, Buntok menunjukkan bahwa belum ada/belum maksimal pembinan yang semestinya diperoleh oleh mualaf untuk meyakinkan akan keislamannya, sehingga kesalehan diri sebagai umat Islam/muslim dapat dijalankan dengan baik.

Namun demikian dari data yang ada, perkembangan /keberadaan mualaf perlu mendapatkan perhatian yang serius dan komitmen bersama untuk memperkuat aqidah, keimanan mereka, sehingga tantangan, dilema yang dialami dapat dijalankan dan diselesaikan dengan baik, bahkan mungkin meningkatkan dan menguatkan keimanan mereka akan Islam ajaran rahmatan lil 'alamin. Islam adalah agama keselamatan, Islam adalah agama damai,

\footnotetext{
${ }^{6}$ Akhmal Hawi. 2014. Seluk Beluk Ilmu Jiwa Agama. PT. Grafindo Persada: Jakarta, h. 35

${ }^{7}$ Agama hanya dimiliki oleh manusia, sehingga manusia disebut juga dengan homo religiosus, yaitu tipe manusia yang hidup disuatu alam yang sakral penuh dengan nilai religius dan dapat dinikmati sakralitas yang ada dan tampak di alam semesta, alam materi, lam tumbuhan-tumbuhan, alam binatang dan alam manusia. lih. Dadang Kahmad. 2009. Sosiologi Agama. Bandung: PT. Remaja Rosdakarya.h.19

${ }^{8}$ Hafidz Muhdhari. 2015. Treatmen dan kondisi Psikologis Muallaf. (jurnal Edukasi) Jurnal Bimbingan Konseling.
} 
mengajarkan kecintaan kepada sesama makhluk yang ada di muka bumi, serta mengajarkan keselamatan di dunia dan di akherat kelak.

\section{Motivasi menjadi Muslim}

Manusia adalah makhluk sosial, makhluk yang tidak bisa lepas dari pengaruh lingkungan sekitarnya, makhluk yang memerlukan adanya bantuan dari orang lainnya, karena manusia memiliki keterbatasan dan tiada sempurna. Manusia secara naluri adalah makhluk yang membutuhkan keberadaan orang lain, dan untuk itulah ia perlu bermasyarakat . ${ }^{9}$ Hidup bermasyarakat berarti hidup berinteraksi dan terlib langsung maupun tidak langsung dengan lingkungan sekitarnya, sehingga bisa merubah pola pikir atau keyakinan seseorang sebagai hasil pengalaman yang dialami dan dijalani oleh seseorang.

Gambaran tentang mualaf di Kalimantan Tengah untuk menjadi seorang muslim, dipengaruhi oleh beberapa kondisi, hal ini juga menjadi gambaran akan keislaman seseorang (mualaf) diawali oleh beberapa faktor yaitu :

1. Faktor perkawinan

2. Faktor ajakan teman, ajakan keluarga

3. Faktor dakwah yang dilakukan oleh da'i, ulama dan penceramah

4. Faktor keinginan dari diri sendiri, dari ketertarikan mempelajari Islam hingga berkeinginan untuk masuk Islam ${ }^{10}$.

Faktor yang paling dominan ( 1 sampai dengan 4 ) adalah karena perkawinan, tatkala seseorang (bukan muslim) baik laki-laki maupun perempuan akan menikah dengan seseorang yang beragama Islam (laki-laki maupun perempuan) maka ada suatu kewajiban, sunah atau prasyarat untuk seagama (Islam), sehingga menjadi muslim, maka dorongan karena perkawinan menjadi faktor yang mayoritas terjadinya perpindahan keyakinan/agama oleh seseorang. Hal ini sebagaimana diungkapkan salah

9 Abuddin Nata. 2014. Sosiologi Pendidikan Islam. Jakarta : PT. Raja Grafindo Persada.h.46

${ }^{10}$ Hasil penelitian yang dilakukan oleh Sabian Utsman dkk , 2017 sd 2018 tentang Pembinaan dan Pemetaan Muallaf di Kalimantan Tengah. 
seorang mualaf : Saya masuk agama Islam karena pacar saya beragama Islam, oleh keluarganya tidak akan memberikan izin jika berbeda agama, bukan hal itu saja karena dalam ajaran Islam tidak boleh kawin beda agama, kondisi ini menjadikan saya harus masuk Islam, saya cinta pada calon isteri saya, maka saya masuk agama Islam, sehingga bisa menikah dengan pacar saya ${ }^{11}$.

Ungkapan lainnya juga dikemukakan oleh salah seorang mualaf : Saya masuk Islam karena dorongan hati nurani, karena pacar saya beragama Islam, lingkungan saya tinggal lingkungan masyarakat Islam, sehingga saya masuk Islam karena kemauan sendiri ${ }^{12}$.

Mengkaji motivasi menjadi muslim dengan berbagai faktor, Allah SWT berfirman dalam Al-Qur'an surah Al-Baqarah ayat 221 yang artinya :

“ Dan janganlah kamu menikahi wanita musyrik, sebelum mereka beriman. Sesungguhnya wanita budak yang mukmin lebih baik dari wanita musyrik manapun, walaupun dia menarik hatimu. Dan janganlah kamu menikahkan orang-orang musyrik ( dengan wanitawanita mukmin) sebelum mereka beriman. Sesungguhnya budak yang mukmin lebih baik dari orang mjusyrik, sedang Allah mengajak ke surga dan ampunan dengan izin-Nya. Dan Allah menerangkan ayatayat-Nya (perintah-perintah-Nya) kepada manusia supaya mereka mengambil pelajaran".

Garisan aturan yang ada dalam ajaran Islam sebagaimana ayat AlQur'an Surah Al-Baqarah ayat 221 tersebut, merupakan amar (perintah) agar keluarga muslim untuk menikahkan muslim dengan pasangan seiman/muslim,

11 Informasi sebagai hasil wawancara dengan salah seorang mualaf yang ada di Kabupaten Kotim, Tahun 2016. Hal ini juga diungkapkan oleh KUA setempat : mereka biasanya mau menikah masuk keagama Islam, namun sebelum menikah sekitar minimal satu minggu masuk agama Islam baru dilangsungkan acara akad nikah, karena mereka harus melengkapi berkas/persyaratan seperti kertas syahadat bukti mereka beragam Islam, maka kami bisa menikahkan mereka dalam ajaran Islam.

${ }^{12}$ Ungkapan yang dikemukakan oleh salah seorang mualaf di Kabupaten Kapuas, tahun 2017. Namun demikian ketika digali kembali pernyataan ini, faktor karena ingin menikah dengan seseorang yang beragama Islam (pacar), seseorang menjadi muslim, karena pihak keluarga sang pacar menolak pernikahan beda agama, sehingga terlebih dahulu masuk agama Islam, terlanjur cinta dan suka, sehingga bersedia untuk menjadi muslim, bersyahadat dengan dibimbing oleh KUA setempat maupun ustadz yang ada di wilayah tersebut. 
motivasi karena perkawinan menjadi dominasi dari sekian faktor yang ada. Namun demikian, hidayah yang muncul dari dorongan eksternal (karena perkawinan) kemudian diikuti dengan motivasi diri (internal) membuat kesalehan seorang muslim untuk menjalankan aktivitas rutinitas ajaran agama dalam Islam seperti : shalat, puasa, zakat maupun ibadah haji (bagi yang mampu) merupakan rukun Islam yang wajib di jalankan oleh seseorang yang telah menyatakan diri sebagai umat Islam, umat Rasulullah SAW.

\section{Kesalehan Muallaf}

Mengupas kesalehan mualaf setelah menganut agama Islam $^{13}$, dapat dilihat melalui bingkai keislaman, yaitu aktivitas yang berkaitan dengan amaliah rutin keagamaan Islam seperti shalat, zakat, dan puasa, sedangkan pelaksanaan ibadah haji (bagian dari rukun Islam), adalah bagi yang mampu (lihat Q.S. Ali Imran ayat 97).

Awal menjadi seorang muslim atau seseorang sebelum beragama Islam, kemudian mengucapkan syahadat (dua kalimat tauhidt) merupakan prasyarat utama seseorang disebut menjadi umat muslim maupun muslimah, istilah yang digunakan dalam Islam adalah mualaf. Pengucapan syahadat tersebut diucapkan oleh seseorang sebagai bukti awal menjadi pemeluk agama Islam, namun demikin, sebagai ucapan syahadah : Laa Ilaaha illallaah-wa asyhadu anna Muhammadarrasulullaah" merupakan pengakuan akan pengakuan Allah sebagai Tuhan dan Nabi Muhammad SAW sebagai Rasul utusan Allah ${ }^{14}$. Karunia yang terbesar diberikan Allah SWT kepada manusia adalah keimanan, dengan keimanan seseorang akan menjadi mashlahat, hidupnya terarah pada keimanan yang diyakininya, demikian juga seseorang

13 Islam didefinisikan secara etimologi, Islam berarti tunduk dan menyerah sepenuhnya pada Allah swt. secara terminologi adalah agama yang dilandasi oleh lima dasar yaitu: 1) syahadatain. 2) menunaikan shalat wajib pada waktunya dengan memenuhi syarat, rukun dan memperhatikan adab dan halhal yang sunnah. 3) mengeluarkan zakat. 4) puasa di bulan Ramadhan. 5) Haji sekali seumur hidup bagi yang mampu, mempunyai biaya untuk pergi ke tanah suci dan mampu memenuhi kebutuhan keluarga yang ditinggalkan . lih. Muștafa al-Bugi, Al-wafi fi syarah al-arba'in an-nawawī (Damaskus: Dār ibn-kas̄īr, 1998), 17.

14 Allah menyatakan bahwasannya tidak ada Tuhan melainkan dia ( yang berhak disembah), yang menegakkan keadilan. Para malaikat dan orang-orang berilmu (juga mengatakan yang demikian). Tak ada Tuhan kecuali hanya Allah (yang berhak disembah), Yang Maha Perkasa lagi Maha Bijaksana. Lih. Q.S. Ali Imran ayat 8). 
yang menjadi muslim maka keimanannya adalah hanya tertuju pada ajaran yang tertuju pada Al-Qur'an dan al-hadis. Keyakinan akan keislaman seseorang (mualaf) meyakinkan akan pengetahuan, kayakinana dan amaliahnya pada tuntunan ajaran Islam, yang diajarkan oleh Rasulullah SAW.

Pengertian Islam secara etimologi, Islam berarti tunduk dan menyerah sepenuhnya kepada Allah swt, secara terminologi adalah agama yang dilandasi oleh lima dasar yaitu : 1) syahadat, 2) menunaikan shalat wajib pada waktunya dengan memenuhi syarat, rukun dan memperhatikan adab dab hal-hal yang sunnah, 3) mengeluarkan zakat, 4) puasa di bulan Ramadhan, 5) haji sekali seumur hidup bagi yang mampu, mempunyai biaya untuk pergi ke tanah suci dan mampu memenuhi kebutuhan keluarga yang ditinggalkan. ${ }^{15}$

Pengucapan dua kalimat shahadat (syahadat) sebagai bagian dari rukun Islam, bukan hanya diucapkan semata, tetapi juga diyakini dan diamalkan, inilah kesempurnaan dari kalimat syahadat.

Kondisi yang menjadi gambaran para mualaf : Kalimat syahadat diucapakan, diucapkan pada saat akan menjadi seorang muslim (pra syahadah), Sebagaimana diungkapkan oleh mualaf : Saya mengucapkan kalimat syahadat pada saat akan masuk Islam, selanjutnya jika saya shalat maka ada juga kalimat syahadat dalam bacaan tahiyat ${ }^{16}$. Beda dengan mualaf diwilayah lain : kalimat syahadat saya ucapkan saat mau masuk agama Islam yang dibimbing oleh ustadz yang akan mengislamkan saya, selanjutnya kalimat itu tak diucapkan lagi ${ }^{17}$. Berbeda dengan apa yang ditemukan dari pendapat dan pengamatan yang dilakukan : ketika diminta kembali untuk mengucapkan kalimat syahadat, ibu W terdiam beberapa saat, kemudia berkata sudah saya ucapkan, begitu

\footnotetext{
${ }^{15}$ Mustafa al Buqi. 1998. Al-Wafi fi syarah al-arba'in an nawawi. Damaskus : Daar IbnKatsir.h.17.

${ }^{16}$ Pengakuan mualaf di wilayah Kotawaringin Timur (Sampit). 2017. Beberapa mualaf diwilayah ini mengucapkan kalimat syahadatpada saat akan masuk agama Islam.

${ }^{17}$ Dialog dengan mualaf di wilayah Danau Pantau kabupaten Kapuas, 2017. Pengakuan Bapak S : bacaan syahadat hanya pada saat masuk agama Islam, lebih ironis mualaf yang merasa hanya sekali bahkan tak bisa lagi mengucapkan syahadat secara sempurna, karena mengucapkan syahadat dibimbing oleh ustadz yang membimbing masuk agam islam, selanjutnya tak diucapkan lagi seirama tidak dilakukan aktivitas keagamaan islam lainnya, hal ini diungkapkan oleh mualaf yang beridentitas muslim namun aktifitas ajaran agama Islam tak rutin bahkan tidak dijalankan. Tanpa ada bimbingan atau pembinaan secara formal maupun informal.
} 
beberapa kali, kemudia dikatakannya saya tak bisa tak hapal lagi bacaan itu karena dibaca hanya pada saat akan masuk Islam itu juga dibimbing oleh bapak KUA setempat. ${ }^{18}$

Kalimat Syahadat akan ditemukan juga pada bacaan-bacaan shalat lima waktu (shalat fardlu), bagi muslim yang rutin mengerjakan ibadah shalat atau aktivitas keagamaan lainnya tentu senantiasa mengucapkan teks syahadat tersebut. Syahadatain berasal dari kata "syahida" yang berarti bersaksi, menghadiri, melihat, mengetahui dan bersumpah. ${ }^{19}$

Beberapa aktivitas keagamaan Islam yang dijalankan oleh mualaf di wilayah Kalimantan Tengah yang akan disoroti pada tulisan ini, meliputi ibadah shalat dan puasa.

\section{a. Ibadah Shalat}

Shalat merupakan kewajiban yang dijalankan oleh umat Islam lima kali dalam sehari, yaitu shalat Subuh, Zuhur, Ashar, Maghrib dan Isya. Secara terminologi shalat adalah seperangkat perkataan dan perbuatan yang dilakukan denganbeberapa syarat tertentu, dimulai dengan takbir dan diakhiri dengan salam. ${ }^{20}$ Kewajiban shalat lima waktu dilaksankan sehari dalam semalam, setiap muslim yang balig lagi berkal wajib untuk mengerjakannya, dalam keadaan apapun.

Informasi tentang aktivitas keagamaan yang dilakukan oleh mualaf yang tersebar dibeberapa wilayah di Kalimantan Tengah dapat diungkapkan dari penyataan mualaf tersebut sebagai berikut.

${ }^{18}$ Pengamatan dan wawancara yang dilakukan pada ibu W. 2017. Berdomisili di Desa Danau Pantau, padahal ibu W sudah memiliki 1 orang putra dan saat di wawancara sedang mengandung 8 bulan. Sungguh dilematis : ibu W (sebelumnya agama Kaharingan) hanya mengucapkan sekali saja pada waktu akan menikah dan juga di dibimbing oleh KUA setempat yang membimbing masuk agama Islam. Kondisi ibu W yang tak bisa /lupa kalimat syahadat stelah diminta mengulng dan dibimbing kembali, ibu W terbata-bata mengucapkannya. Mengamati lingkungan rumah tempat ibu W terpajang lukisan kaligrafi dan foto-foto ulama kharismatik di ruangan tamu, ternyata tidak menunjukkan situasi keagamaan penghuni rumah. Ibu W juga jarang melaksanakan shalat dan puasa, namun masih meminta anaknya untuk melaksanakan ibadah tersebut dan menempatkan anak untuk mengikuti pendidikan Islam di Tka BKPRMI yang ada di masjid tempat mereka tinggal (berjarak sekitar $2 \mathrm{~km}$ ). Persada.h. 250

19 Abdul Mujib. 2006. Kepribadian Dalam Psikologi Islam. Jakarta : PT. Raja Grafindo

${ }^{20}$ Supiana dan M. Karman. 2009. Materi Pendidikan Agama Islam. Bandung : Remaja Rosdakarya.h.4. 
1. Saya shalat kadang-kadang saja, terutama pada bulan Ramadhan/bulan puasa, karena orang banyak shalat di masjid, saya ikut aja tapi kalau hari lainnya kadang shalat kadang tidak. ${ }^{21}$

2. Saya mengerjakan shalat kalau lagi ada di tempat ibu mertua, di Kota Buntok,..nah kalau dirumah ini di Kampung saya tak shalat, karena tidak ada mukena, kalau di tempat mertua ada mukena, juga mertua mengajak saya untuk shalat. ${ }^{22}$

3. Alhamdulillah.. untuk shalat lima waktu saya bisa rutin kerjakan, suami saya selalu mengajak saya, saya juga kadang shalat berjamaah dimasjid, awalnya sih agak bingung juga, seperti setelah shalat saya perhatikan orang shalat dismaping saya pegang tasbih saya ikut juga gaya pegang tasbih, tapi tak tahu apa yang dibaca, namun lama-lama saya mengethaui apa yang dibaca dengan memegang tasbih, kadang shalat di rumah suami yang jadi imam. ${ }^{23}$

4. Saya shalat lima waktu alhamdulillah dapat dijalankan, walaupun pada awalnya kesulitan membaca ayat, tapi saya coba belajar sendiri dan mencari guru atau ustadz yang dapat mengajari saya, sampai saat inipun saya masih terus untuk belajar, walaupun ayat yang saya baca masih

${ }^{21}$ Wawancara dengan ibu W, tahun 2017. Desa Danau Pantau Kabupaten Kapuas. Demikian juga diperkuat dalam pengamatan penulis, di desa tersebut terdapat sebuah masjid yang sederhana sebagai tempat ibadah umat islam yang ada di lingkungan Desa danau Pantau, walaupun ada masjid lainnya namun terletak jauh dari lingkungan desa ini, sehingga masyarakat di desa ini memanfaatkan masjid yang ada dilingkungan desa mereka saja. Keberadaan masjid juga swadaya dari organisasi keislaman dan aktif memberikan pembinaan keagamaan islam kepada masyarakat yang ada di Desa danau Pantau.

${ }^{22}$ Wawancara dengan ibu R. 2018. Kabupaten Barito Selatan/Buntok.

${ }^{23}$ Wawancara dengan ibu M. 2018. Buntok. Ibu M adalah salah satu jamaah majlis taklim yang aktif mengikuti pengajin yang ada di Kabupaten Buntok. Bimbingan dari suami juga diperolehnya. Aktivitas majlis taklim senantiasa dia ikuti dan aktif bertanya pada hal-hal yang kurang dipahaminya pada saat mengikuti kegiatan majlis. Demikin juga pada saat penelitian ini dilakukan, sehingga kajian penelitian sekaligus memberikan bekal keislaman kepada para mualaf yang aktif bertanya tentang keislaman. 
ayat yang pendek saja : surah al-Fatihah, surah al-Ikhlas, surah an-Nash juga surah al-Kautsar, saat saya tidak bekerja saya baca buku agama Islam, jika saya tak paham maka saya tanyakan pada ustadz yang lebih tahu. $^{24}$

Informasi yang diperoleh dari para mualaf tersebut memberikan gambaran bahwa aktivitas dalam ajaran agama Islam seperti shalat masih memerlukan proses pembelajaran, hal ini juga memberikan kontribusi bahwa pembimbingan kepada para mualaf sebagai umat Islam yang masih memerlukan penghayatan/pendalaman serta bimbingan aktivitas keislamannya.

Amaliah mualaf pada wilayah lainnya juga menggambarkan kondisi yang serupa, akan tetapi keyakinan akan Islam sebagai agama yang dianut, seorang mualaf yang terpanggil hatinya untuk mempelajari agama Islam kemudian menjadi muslim :

saya mempelajari Islam sebelum perkawinan, belajar melalui referensi buku dan kajian-kajian Islam yang ada di internet, di youtube dan bertanya kepada guru-guru mengaji, hingga saya menikah dengan seseorang (sekarang adalah suami saya), dia meyakinkan saya untuk menjadi muslim, bakan turun membimbing saya. Setelah saya menjadi muslim banyak tantangan dari keluarga hingga saya diabaikan dari keluarga. Akan tetapi kepuasan akan ajaran Islam senantiasa saya baca dan pelajari di internet, setiap hari saya mendengarkan bimbingan agam Islam dan jika ada yang kurang dipahami saya tanyakan pada suami juga pada guru-guru agama, Alhamdulillah saya sekarang bisa dengan tenang menjalankan ajaran agama yang saya anut saat ini, walaupun sampai sekarang keluarga saya masih mengabaikan saya, saya ettap baik dengan mereka. ${ }^{25}$

${ }^{24}$ Informasi bapak G, 2017. Kabupaten Kotim / Sampit. Bapak G adalah mualaf keturunan China yang bekerja dari pagi sampai sore, namun masih menyediakan waktu untuk mempelajari agama islam setelah bekerja. Dia senantiasa belajar untuk mendalami agama islam, komitmennya untuk dapat menjalankan aktivitas kewajiban dalam islam dia berupaya untuk menjalankannya.

${ }^{25}$ Wawancara dengan Ibu MH, 2018. Buntok (kabupaten Barito Selatan). Sebelumnya Ibu MH beragama Kristen. Kesehariannya aktif mengikuti pengajian, majlis taklim dilingkungan sekitar juga dilingkungan kerjanya, sang suami senantiasa membimbing dan mendorongnya untuk dapat menjalankan ajaran agama Islam dengan baik, shalat, puasa, membaca Al-Qur'an telah menamatkan bacaan Qur'an dengan baik, bahkan bisa mengajarkan pada anak-anaknya. 
Mualaf yang senantiasa memulai keislaman, tertarik dengan ajaran Islam, berusaha mempelajari ajaran Islam, maka aktivitas keagamaan Islam yang menjadi kewajiban seorang muslim akan dapat dijalankan dengan baik, walaupun kesempurnaan pelaksanaan selalu dalam perbaikan.

\section{b. Puasa}

Ibadah puasa yang wajib dijalankan dalam rukun Islam adalah puasa di Bulan Ramadhan. Rangkaian dari pelaksanaan ibadah puasa juga terkandungan kewajiban menunaikan zakat fitrah yang wajib dikeluarkan oleh muslim dari awal bulan Ramadhan hingga menjelang waktu shalat idul Fitri.

Pelaksanaan ibadah puasa di bulan Ramadhan yang lakukan oleh mualaf sebagai berikut.

1. Puasa Ramadhan alhamdulillah saya bisa kerjakan, walaupun pada awalnya rasanya berat, haus, lapar dan lemah badan saya, tapi lama kelaman karena terbiasa saya jadi biasa. Badan saya jadi sehat, bahkan saya juga membaca di buku bahwa puasa menyehatkan, saya juga bertanya ke ustadz saya kenapa puasa menyehatkan, saya jadi tak ada beban dalam menjalankan puasa di bulan Ramadhan, apalagi saya puasa suasa lingkungan saya bekerja juga mendukung, teman sekerja banyak yang Islam dan mereka puasa.. alhamdulillah puasa saya tunai setiap tahunnya. Zakat fitrah juga saya bisa tunaikan, karena ini adalah kewajiban saya sebagai umat Islam. ${ }^{26}$

2. Saya tak kuat puasa, tapi bulan puasa kadang puasa juga siang hari buka, apalagi kalau saya lagi hamil, saya tidak puasa sama sekali, badan rasanya tak berdaya. Suami saya juga tak melarang saya tidak puasa apalagi saat saya hamil, Kalau tidak hamil saya sebulan mungkin 2 atau 3 hari saja puasa dari pagi sampai sore... untuk zakat apa yang

\footnotetext{
${ }^{26}$ Wawancara dengan bapak G, 2017. Kabupaten Kotim, Sampit.
} 
dibayarkan di bulan puasa sih bayar jika suami yang bayarkan, sya hanya ibu rumah tangga tidak bekerja. ${ }^{27}$

3. Puasa di bulan Ramadhan saya belum bisa kerjakan, tidak kuat, apalagi suami saya sering pergi kerja tak ada teman untuk saya puasa, anak saya masih kecil, kalau dia makan-makan saya jadi tergoda..kalau bayar zakat dibualn puasa/Ramadhan dibayarkan. Kalau lagi ditempat mertua saya juga tak kuat puasa, siang buka. ${ }^{28}$

4. Puasa ramadhan alhamdulillah saya tunai, kalau pertama kali saya baru masuk Islam, saya puasa tidak sempurna sebulan tersebut, kdang siang ada buka. Tapi sekarang saya tunai sebulan penuh. Suami saya senantiasa membimbing dan mendorong saya untuk dapat menjalankan puasa sampai tunai, juga motivasi dari majlis taklim yang saya ikuti. Dalam seminggu saya ikut majlis taklim 3 kali, untuk bayar zakat fitrah alhamdulillah tunai. ${ }^{29}$

Aktivitas keagamaan melalui ibadah shalat lima waktu dan puasa serta zakat yang digambarkan oleh para mualaf dari beberapa wilayah cukup signifikan memberikan informasi akan kesalehan seorang setelah menjadi muslim. Kesalehan seseorang ditunjukkan dengan kematangan akan pemahaman terhadap agama, dapat dilihat pada: 1)Pemahaman terhadap agama, 2) Aktualisasi terhadap ajaran agama dan 3) Faktor yang turut mempengaruhi.

Pemahaman terhadap agama (Islam) bagi seorang mualaf, diperoleh keinginan untuk menjadi muslim karena internal ataupun ekternal (dipengaruhi oleh kemuan diri sendiri maupun luar dirinya), akan

${ }^{27}$ Wawancara dengan Ibu W. 2017. Desa Danau Pantau. Kabupaten Kapuas. Kondisi ibu W dimana pekerjan suami yang kadang memotivasi kadang tidak pada aktivitas keagamaan pada shalat dan puasa ibu W adalah : suami sebagai pekerja tambang, terkadang pergi untuk menambang hingga seminggu bahkan satu bulan baru kembali ke Desa. Kondisi ini juga yang kurang memperhatikan atau memotivasi ibu W untuk menjalankan ibadah/kewajiban dalam ajaran Islam. Bahkan sang suami shalat lima waktu kadang diljalankan terkadang tidak.

${ }^{28}$ Ibu R adalah mualaf yang sudah 4 tahun menjadi muslim, sehingga pengetahuan agama yang dimiliki masih perlu bimbingan. Sang suami yang lebih dekat dengannya jarang berada di rumah karena harus bekerja, bekerja berenagkat pagi pulang menjelang maghrib.

${ }^{29}$ Ibu M adalah mualaf yang senantiasa dibimbing suami juga melalui ustadz ustadzah yang diikuti pada saat majlis taklim, penguatan yang diperolehnya snagat mendukung pengetahuan dan amaliah ibu M. 2018. Kabupaten Barito Selatan/Buntok. 
mewarnai amaliah keagamaan Islam yang akan dijalankannya, namun banyak faktor yang akan mewarnai keislamnnya, seperti : lingkungan keluarga, lingkungan masyarakat sekitar ( formal maupun informal) serta motivasi dalam dirinya untuk meyakinkan akan keimanannya pada Islam sebagai agama yang dianutnya.

Iman yang benar adalah diyakini dengan hati, diucapkan dengan lidah dan dibuktikan dengan amaliah. Sebagaimana yang diungkaapkan oleh Mustofa bahwa berislam bukan hanya beriman, tetapi juga beramal, dalam hal ini , setiap muslim dituntut untuk mengamalkan apa yang diimaninya. Islam adalah mempunyai makna kedamaina, kepatuhan, penyerahan (diri), ketaatan dan kepatuhan. Hal ini berlaku bagi mereka yang mengalami perpindahan agama dari agama non Islam kepada agama Islam (muallaf). ${ }^{30}$

Kesalehan pada ajaran agama Islam bagi mualaf (mereka yang mengalami perpindahan agama kepada agama Islam) diberikan untuk memperkuat keyakinan dan pemberian pengetahuan untuk selanjutnya dapat mengamalkan ajaran agama Islam dengan baik, namun secara universal pemantapan keimanan, pemantapan akidah Islam juga diperlukan oleh umat Islam yang semenjak lahir telah beragama Islam. Komitmen beragama untuk semua umat Islam, pencapaian kesalehannya dalam bingkai Islam sebagai agama rahmatan lil alamin merupakan suatu keharusan yang tiada henti. Karena iman adalah pembuktiannya dengan amaliah nyata, bukan hanya pengucapan dan keyakinan belakang.

\section{KESIMPULAN}

Keimanan pada ajaran Agama Islam diyakini dengan hati, diungkapkan dengan kata-kata dan dibuktikan dengan amal nyata / amaliah. Konsekuensi sebagai umat Islam pada mualaf bukan hanya mengucapkan syahadat namun juga dibingkai dengan kesalehan pada amaliah ajaran agama sehingga keislaman diperoleh dan dijalankan secara kaffah. Namun demikian bimbingan keagamaan

\footnotetext{
${ }^{30}$ Mustofa Kurdi. 2012. Dakwah Dibalik Kekuasaan. Bandung : Remaja Rosdakarya.h.121.
} 
Islam masih sangat diperlukan oleh para mualaf, hal ini menjadi kewajiban bersama baik secara individu maupun kelompok, baik formal maupun non formal, sehingga semakin kuat keyakinan mualaf pada ajaran agama Islam sebagai agama rahmatan lil alamin. 


\section{DAFTAR PUSTAKA}

Nata, Abuddin. 2014. Sosiologi Pendidikan Islam. Jakarta : PT. Raja Grafindo Persada

Al-Bugi. Mușțafa. 1998. Al-Wafi fi Syaraḥ al-Arba'in an-Nawaw̄i .Damaskus: Dār ibn-kas̄īr.

Hawi, Akhmal . 2014. Seluk Beluk Ilmu Jiwa Agama. PT. Grafindo Persada: Jakarta.

Kurdi. Mustofai. 2012. Dakwah Dibalik Kekuasaan. Bandung : Remaja Rosdakarya

Kahmad. Dadang. 2009. Sosiologi Agama. Bandung: PT. Remaja Rosda-karya

Supiana dan M. Karman. 2009. Materi Pendidikan Agama Islam. Bandung : Remaja Rosdakarya

Mujib. Abdul. 2006. Kepribadian Dalam Psikologi Islam. Jakarta : PT. Raja Grafindo Persada

Muhdhari. Hafidz. 2015. Treatmen dan kondisi Psikologis Muallaf. (jurnal Edukasi) Jurnal Bimbingan Konseling

Perpustakaan Nasional R.I. 2006. EnsiklopeDI Hukum Islam. Jakarta.

Penyusun Depdikbud. 1999. Kamus Besar Bahasa Indonesia. Jakarta : Balai Pustaka.

Sabian, dkk. 2017. Penelitian Kelompok. Pemetaan dan pembinaan Muallaf di Kalimantan Tengah.

https://id.m.wikipedia.org, up date 1 Maret 2019. 